\title{
The Effect of Ethrel Application on Length of the Juvenile Phase of Apple Seedlings
}

\author{
Edward Żurawicz ${ }^{1}$, Kris Pruski ${ }^{2} \&$ Mariusz Lewandowski ${ }^{1}$ \\ ${ }^{1}$ Fruit Breeding Department, Research Institute of Horticulture, Skierniewice, Poland \\ ${ }^{2}$ Department of Plant \& Animal Sciences, Dalhousie University, Truro, Canada \\ Correspondence: Kris Pruski, Department of Plant \& Animal Sciences, Dalhousie University, Faculty of \\ Agriculture, P.O. Box 550, Truro, NS, B2N 5E3 Canada. Tel: 1-902-893-6032, 1-902-986-4004. E-mail: \\ kris.pruski@dal.ca
}

Received: April 16, 2013 Accepted: May 30, 2013 Online Published: July 15, 2013

doi:10.5539/jas.v5n87p17 URL: http://dx.doi.org/10.5539/jas.v5n87p17

\begin{abstract}
A 10 year study (1998-2007) was conducted to work out a method that would allow shortening of the juvenile phase of apple seedlings in conventional apple breeding programs. The investigation was based on two separate experiments, each conducted first in high plastic tunnel and then in the field. In both experiments in the first two years, the seedlings were grown on their own roots in plastic containers (cylinders) placed in the high plastic tunnels. At the end of the second year (December), shoot tips from the seedlings were collected and grafted onto dwarfing rootstock M.9 (winter grafting). By the end of March, the grafts were planted in plastic containers and placed in the same high plastic tunnel. They were cultivated there until mid - August and then planted out to the selection field. In the first experiment, seedlings belonging to two families, 'Ligol' $\mathrm{x}$ 'Delbard Jubile' and 'Linda' $\mathrm{x}$ 'Golden Delicious' were investigated. In the second experiment, two seedling populations, 'Free Redstar' $\mathrm{x}$ 'Melodie" and 'Free Redstar' x 'Coop 38' were tested as well. In the first experiment, nine experimental treatments were studied. They involved two growing media (peat substrate and mixture of peat substrate with compost soil 1:1), two mineral fertilizers (Osmocote Plus and Azofoska - the Polish manufactured fertilizer) and two bioregulators (Gibrescol $10 \mathrm{MG}$ containing $\mathrm{GA}_{3}$ and Ethrel). In the second experiment, additionally compost soil was included. It was found that Ethrel applied twice on young apple seedlings grown in high plastic tunnel, in the first and second year of cultivation in both experiments, shortened the juvenile stage of seedlings grafted and grown on M.9 rootstock. In the first year after planting in the selection field (fourth year after seed germination), $25 \%$ of the seedlings produced flowers, and in the second year all of them flowered and produced fruits.
\end{abstract}

Keywords: Malus x domestica, ethephon, breeding, selection, juvenility, fruiting

\section{Introduction}

The juvenile phase is the period in the life cycle of woody plants in which they are unable to produce flowers and fruits. The long juvenile stage of apple seedlings prolongs the time of conventional breeding new apple cultivars and substantially increases costs of breeding programs. In apple seedlings, the length of the juvenile stage depends on the parental genotypes used in the crossing program and may last from 5 to 12 years (Visser, 1964; Fischer, 1994). To lower the costs of apple breeding and to increase its effectiveness apple breeders conducted in the past different studies to accelerate the first flowering of apple seedlings. These involved primarily the agro-technical approaches such as promoting the intensive growth of seedlings, grafting seedlings' tops (scions) onto dwarfing rootstocks, trunk ringing, bark scoring inversion, root pruning, stem defoliation and others. A review of different agro-technical approaches to induce early flowering of apple seedlings has been given by Flachovsky et al. (2009). There are many reports in the literature indicating that application of different plant growth regulators, including 2-chloroethylphoshonic acid (Ethrel, ethephon) can affect the flower differentiation and fruiting of cultivated varieties (Luckwill, 1973; Katzfuss \& Schmidt, 1986; Hamad \& Mohammad, 1990). However, there are only reports on application of ethephon to promote early flower differentiation in apple seedlings. Kender (1971) reported applying ethephon as a foliar spray at different concentrations to 3, 4, and 5 year old apple seedlings in 1969 and 1970. The percentage of trees flowering for the first time in 1970 was significantly increased by application of ethephon at $1000 \mathrm{ppm}$ over control. The number 
of flower clusters per tree was also increased by ethephon treatment over controls. In this study ethephon applied to young Spijon trees in the greenhouse resulted in an increase in the number of flower clusters produced. The author indicated that this technique may be useful in inducing early fruiting in breeding lines. Guo, Guo, and Zan (1992) also studied the effect of spraying growth retardants on the duration of the juvenile stage of apple seedlings. His results indicated that spraying with PP333 at $1000 \mathrm{ppm}+$ ethephon at $1000 \mathrm{ppm}$ was the most effective treatment in shortening the juvenile stage. Good treatments were also PP333 at $1500 \mathrm{ppm}$ and ethephon at $1000 \mathrm{ppm}$. The aim of the studies presented in this publication was to shorten the juvenile stage of apple seedlings in the classical apple breeding program through different agro-technical approaches applied in combination with the use of plant growth regulators.

\section{Methods and Materials}

Investigation was based on two separate experiments: Experiment 1 - conducted between 1998 and 2005 and Experiment 2 - conducted between 2000 and 2007. Both experiments were conducted in a similar way - first two years in the high plastic tunnel and then in the open field. In both experiments apple seedlings belonging to two different hybrid families were studied. Seedlings studied in Experiment 1 were derived from the cross made between 'Ligol' $x$ 'Delbard Jubilee' and 'Linda' $x$ 'Golden Delicious' and in Experiment 2 seedlings were obtained from a cross made between 'Free Redstar' x 'Melodie' and 'Free Redstar' x 'Coop 38'. Following stratification, germinating seeds (February, 1999, 2001) were planted individually into small pots filled with mixture of peat substrate, compost soil and sand in proportion 1:1:1. Pots were placed in the glasshouse at $22 / 18^{\circ} \mathrm{C}$ day/night temperature with artificial lighting (High-Pressure Sodium Lamps) at irradiance of 310 $\mu \mathrm{mol} \mathrm{m}^{-2} \mathrm{~s}^{-1}$ with $16 \mathrm{~h}$ photoperiod. When seedlings grew to the height of about $10 \mathrm{~cm}$ (about mid-April, 1999, 2001), they were transplanted into black plastic containers containing about $8 \mathrm{dm}^{3}$ of growing medium and placed into the high plastic tunnel. They were there grown on their own roots for two years. In the first experiment, nine experimental treatments were studied. They involved two growing media (commercial peat substrate and mixture of peat substrate with compost soil in proportion 1:1), two mineral fertilizers (Osmocote Plus and Polish manufactured fertilizer Azofoska) and two bioregulators (Gibrescol $10 \mathrm{MG}$ containing $\mathrm{GA}_{3}$ and Ethrel) applied in the combinations shown in Table 1. In the second experiment, similar treatments were studied but additionally compost soil was included as the growing medium (Table 2). Both fertilizers were applied at following doses directly after planting of seedlings: Osmocote Plus - $16 \mathrm{~g} /$ container and Azofoska - 16 $\mathrm{g} /$ container and additionally $8 \mathrm{~g} /$ container 2 month later. Gibrescol $10 \mathrm{MG}\left(10 \%\right.$ giberelic acid $\left.\mathrm{GA}_{3}\right)$ was applied as foliar spray at concentration $200 \mathrm{mg} / 1 \mathrm{~L} \mathrm{H}_{2} \mathrm{O}, 8$ times in each growing season, every 15 days, from May $15^{\text {th }}$ to August $31^{\text {st }}$ ). Ethrel $480 \mathrm{SL}$ ( $480 \mathrm{~g}$ ethephon in 1litre) was applied as one foliar spray at concentration of 2000 $\mathrm{ppm}$ in each growing season on September $15^{\text {th }}$. Characteristics of the growing media and fertilizers used in the experiments are given in Tables 3 and 4 . At the end of the second year of growing seedlings on their own roots in high plastic tunnels (December 2000 and 2002), tops of the seedlings (scions) were collected and grafted onto virus-free M.9 rootstocks in March 2001 and 2003 (winter grafting). At the beginning of April, the grafts were planted into the 8 liter black plastic containers filled with the same growing media in which seedlings were grown on their own roots. Plants were fertilized as in the two previous years but no plant growth regulators were applied. By mid-August of the same year, the grafts reached height of about $150 \mathrm{~cm}$ and were planted out into the open field. In both experiments each treatment comprised of 32 seedlings divided into 4 replications (blocks) with 8 plants in each replicate. The plants under high tunnel and these transplanted to the field were irrigated and fertigated using automatically controlled drip irrigation system. Results concerning the growth vigour and yielding of seedlings were statistically analyzed using the analysis of the variance technique and the means were separated by Duncan's multiple range test at $\mathrm{P}=5 \%$. 
Table 1. Height of apple seedlings (cm) on their own roots in December 1999 and December 2000 grown in high plastic tunnel (Experiment 1)

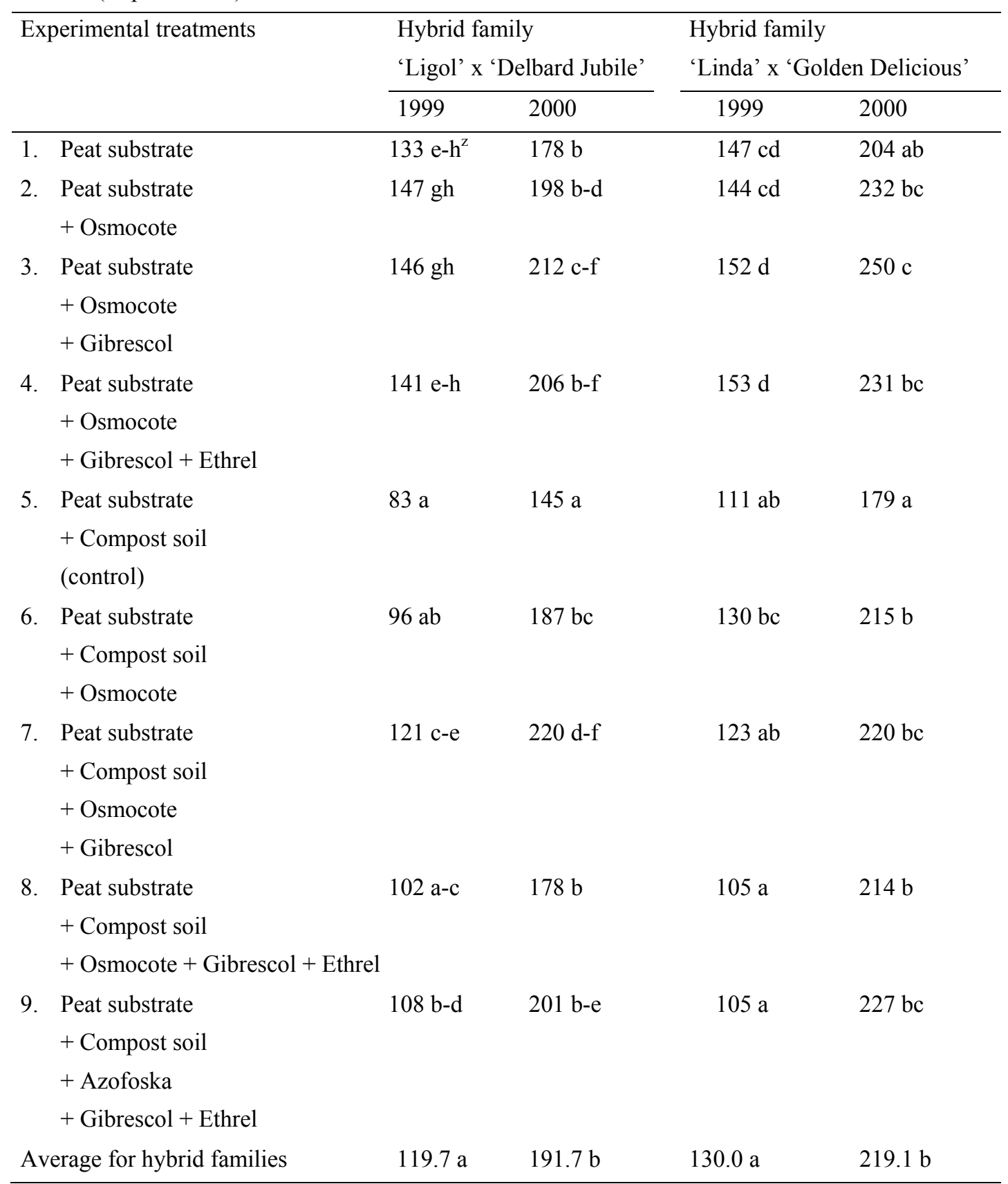

${ }^{\mathrm{z}}$ Means in the columns followed by the same letter do not differ significantly at $\mathrm{P}=0.05$ according to Duncan's multiple range test. 
Table 2. Height of apple seedlings (cm) on their own roots in December 2001 and December 2002 grown in high plastic tunnel (Experiment 2)

\begin{tabular}{|c|c|c|c|c|c|}
\hline \multirow{2}{*}{\multicolumn{2}{|c|}{ Experimental treatments }} & \multirow{2}{*}{\multicolumn{2}{|c|}{$\begin{array}{l}\text { Hybrid family } \\
\text { 'Free Redstar' x 'Melodie' }\end{array}$}} & \multirow{2}{*}{\multicolumn{2}{|c|}{$\begin{array}{l}\text { Hybrid family } \\
\text { 'Free Redstar' x 'Coop 38' }\end{array}$}} \\
\hline & & & & & \\
\hline & & \multirow{2}{*}{$\begin{array}{l}2001 \\
135 \mathrm{a}^{z}\end{array}$} & \multirow{2}{*}{$\begin{array}{l}2002 \\
168 \mathrm{a}\end{array}$} & \multirow{2}{*}{$\begin{array}{l}2001 \\
129 \mathrm{ab}\end{array}$} & \multirow{2}{*}{$\begin{array}{l}2002 \\
229 \mathrm{bc}\end{array}$} \\
\hline 1. & Peat substrate & & & & \\
\hline 2. & $\begin{array}{l}\text { Peat substrate } \\
+ \text { Osmocote }\end{array}$ & $132 \mathrm{a}$ & $210 \mathrm{~b}$ & $134 \mathrm{a}-\mathrm{c}$ & $218 \mathrm{a}-\mathrm{c}$ \\
\hline 3. & $\begin{array}{l}\text { Peat substrate } \\
+ \text { Osmocote } \\
+ \text { Gibrescol }\end{array}$ & $135 \mathrm{a}$ & $227 \mathrm{bc}$ & $110 \mathrm{a}$ & $203 \mathrm{ab}$ \\
\hline 4. & $\begin{array}{l}\text { Peat substrate } \\
+ \text { Osmocote } \\
+ \text { Gibrescol } \\
+ \text { Ethrel }\end{array}$ & $151 \mathrm{a}$ & $271 \mathrm{c}-\mathrm{e}$ & $144 \mathrm{bc}$ & $261 \mathrm{de}$ \\
\hline . & $\begin{array}{l}\text { Peat substrate } \\
+ \text { Azofoska } \\
+ \text { Gibrescol } \\
+ \text { Ethrel }\end{array}$ & $181 \mathrm{~b}$ & $309 \mathrm{e}$ & $156 \mathrm{c}$ & $297 \mathrm{f}$ \\
\hline 6. & Compost soil & $131 \mathrm{a}$ & 290 de & $140 \mathrm{bc}$ & $271 \mathrm{ef}$ \\
\hline 7. & $\begin{array}{l}\text { Peat substrate } \\
+ \text { compost soil (control) }\end{array}$ & $131 \mathrm{a}$ & $260 \mathrm{~cd}$ & $121 \mathrm{ab}$ & $191 \mathrm{a}$ \\
\hline 8. & $\begin{array}{l}\text { Peat substrate } \\
+ \text { compost soil } \\
+ \text { Osmocote }\end{array}$ & $140 \mathrm{a}$ & $262 \mathrm{~cd}$ & $125 \mathrm{ab}$ & $237 \mathrm{~cd}$ \\
\hline 9. & $\begin{array}{l}\text { Peat substrate } \\
+ \text { compost soil } \\
+ \text { Osmocote } \\
+ \text { Gibrescol }\end{array}$ & $133 \mathrm{a}$ & $232 \mathrm{bc}$ & $124 a b$ & $230 \mathrm{bc}$ \\
\hline 10. & $\begin{array}{l}\text { Peat substrate } \\
+ \text { Compost soil+ Osmocote } \\
+ \text { Gibrescol } \\
+ \text { Ethrel }\end{array}$ & $138 \mathrm{a}$ & $241 \mathrm{bc}$ & $122 a b$ & $238 \mathrm{~cd}$ \\
\hline 11. & $\begin{array}{l}\text { Peat substrate } \\
+ \text { Compost soil } \\
+ \text { Azofoska } \\
+ \text { Gibrescol } \\
+ \text { Ethrel }\end{array}$ & $133 \mathrm{a}$ & $242 \mathrm{bc}$ & $110 \mathrm{a}$ & $204 \mathrm{ab}$ \\
\hline Ave & rage for hybrid families & $140.0 \mathrm{a}$ & $246.6 \mathrm{~b}$ & $128.6 \mathrm{a}$ & $234.5 \mathrm{~b}$ \\
\hline
\end{tabular}

${ }^{\mathrm{z}}$ Means in the columns followed by the same letter do not differ significantly at $\mathrm{P}=0.05$ according to Duncan's multiple range test. 
Table 3. The $\mathrm{pH}$ and content of macroelements in growing media used in production of seedlings in high plastic tunnel on their own roots and grafted on M.9 in Experiment 1 and Experiment 2

\begin{tabular}{llcccc}
\hline \multirow{2}{*}{ Growing medium } & \multirow{2}{*}{$\begin{array}{l}\mathrm{P} \\
\mathrm{mg} / 100 \text { g of growing medium }\end{array}$} \\
\hline \multirow{2}{*}{ Experiment 1 } & Peat substrate & 5.8 & 16.5 & 45.4 & 14.0 \\
& Mixture of peat substrate and compost soil (1:1) & 6.5 & 15.8 & 48.4 & 13.2 \\
\hline \multirow{3}{*}{ Experiment 2 } & Peat substrate & 5.8 & 17.6 & 49.8 & 15.7 \\
& Compost soil & 6.6 & 18.2 & 51.6 & 14.9 \\
& Mixture of peat substrate and compost soil (1:1) & 6.3 & 16.2 & 50.1 & 14.4 \\
\hline
\end{tabular}

Table 4. Composition of mineral fertilizers used in production of seedlings in high plastic tunnel on their own roots and grafted on M.9 in Experiment 1 and Experiment 2

\begin{tabular}{llllllllllll}
\hline \multirow{2}{*}{ Type of fertilizer } & $\begin{array}{l}\mathrm{N} \\
(\%)\end{array}$ & $\begin{array}{l}\mathrm{P}_{2} \mathrm{O}_{5} \\
(\%)\end{array}$ & $\begin{array}{l}\mathrm{K}_{2} \mathrm{O} \\
(\%)\end{array}$ & $\begin{array}{l}\mathrm{MgO} \\
(\%)\end{array}$ & $\begin{array}{l}\mathrm{Fe} \\
(\%)\end{array}$ & $\begin{array}{l}\mathrm{Mn} \\
(\%)\end{array}$ & $\begin{array}{l}\mathrm{Cu} \\
(\%)\end{array}$ & $\begin{array}{l}\mathrm{B} \\
(\%)\end{array}$ & $\begin{array}{l}\mathrm{Mo} \\
(\%)\end{array}$ & $\begin{array}{l}\mathrm{Zn} \\
(\%)\end{array}$ \\
\hline \multirow{2}{*}{ Experiment 1 } & Osmocote Plus 8-9 & 16.0 & 8.0 & 12.0 & 2.0 & 0.4 & 0.06 & 0.05 & 0.02 & 0.02 & 0.015 \\
& Azofoska & 13.6 & 6.4 & 19.1 & 4.5 & 0.27 & 0.045 & 0.18 & 0.045 & 0.082 & 0.045 \\
\hline \multirow{2}{*}{ Experiment 2 } & Osmocote Plus 5-6 & 15.0 & 10.0 & 12.0 & 2.0 & 0.4 & 0.06 & 0.05 & 0.02 & 0.02 & 0.015 \\
& Azofoska & 13.6 & 6.4 & 19.1 & 4.5 & 0.27 & 0.045 & 0.18 & 0.045 & 0.082 & 0.045 \\
\hline
\end{tabular}

\section{Results and Discussion}

Results showing effects of the studied treatments on the growth of seedlings belonging to the four different apple hybrid families are presented in Tables 3 and 4, and in Figures 1-4. It can be seen from these tables that the height of seedlings in each experiment was dependent on: (i) the parental forms used for the crosses and (ii) on the experimental treatments studied. However, independently of the parentage and applied treatment combinations seedlings grown on their own roots in high plastic tunnel reached on average the height of about of $200 \mathrm{~cm}$ or even well exceeded this height by the end of the second year. It means that the way we cultivated our seedlings was very efficient in promoting their vigor allowing them become much taller (about $50 \%$ taller) compared to the traditional cultivation in open ground. Fischer (1994) informed that in general the part above $180 \mathrm{~cm}$ stem height in apple seedling is mature (adult) and can be used as scion, and directly grafted onto M.9 rootstocks. In such case, some of the trees begin to flower even three years after seeding instead of conventional 5 to 12 years. In the above studies she was producing seedlings for two consecutive years in the glasshouse supplemented with additional artificial light sources starting from January. This system was efficient in getting tall seedlings but was much more expensive than measures used for promoting growth of seedlings in our studies. Our seedlings on average were taller than $180 \mathrm{~cm}$. In spite of that, not all trees (obtained from grafting of the seedlings scions onto the dwarf M.9 rootstock) flowered and produced fruits in the first year after planting into selection field (fourth year after germinating) (Figures 1-4). Depending on the parentage of seedlings and the experimental treatment applied, the percentage of flowering and fruiting seedlings varied from 0 to $41 \%$. In each hybrid family the greatest number of flowering and fruiting seedlings was observed in those treatments where Ethrel was applied on seedlings grown on their own roots in a high plastic tunnel. The proportion (share) of the fruiting seedlings in this treatment varied from 25 to $41 \%$. In the second year after planting of grafted seedlings into the field (fifth year after seed germinating), the number of fruiting seedling has increased. However, independently of the parentage, $100 \%$ of flowering and fruiting seedlings was observed only in the treatment where Ethrel was applied. These seedlings produced enough fruits to evaluate them for the quality traits. All of these seedlings also produced fruits in the consecutive 2 years when the experiment was conducted, while all the seedlings $(100 \%)$ from other treatments produced fruits two years later. So, our results coincide with the earlier reports of Kender (1971) and Guo et al. (1992) who also informed that ethephon has a very beneficial effect on shortening the juvenile phase of apple seedlings and can promote the formation of flower buds in these seedlings much earlier than untreated controls. 


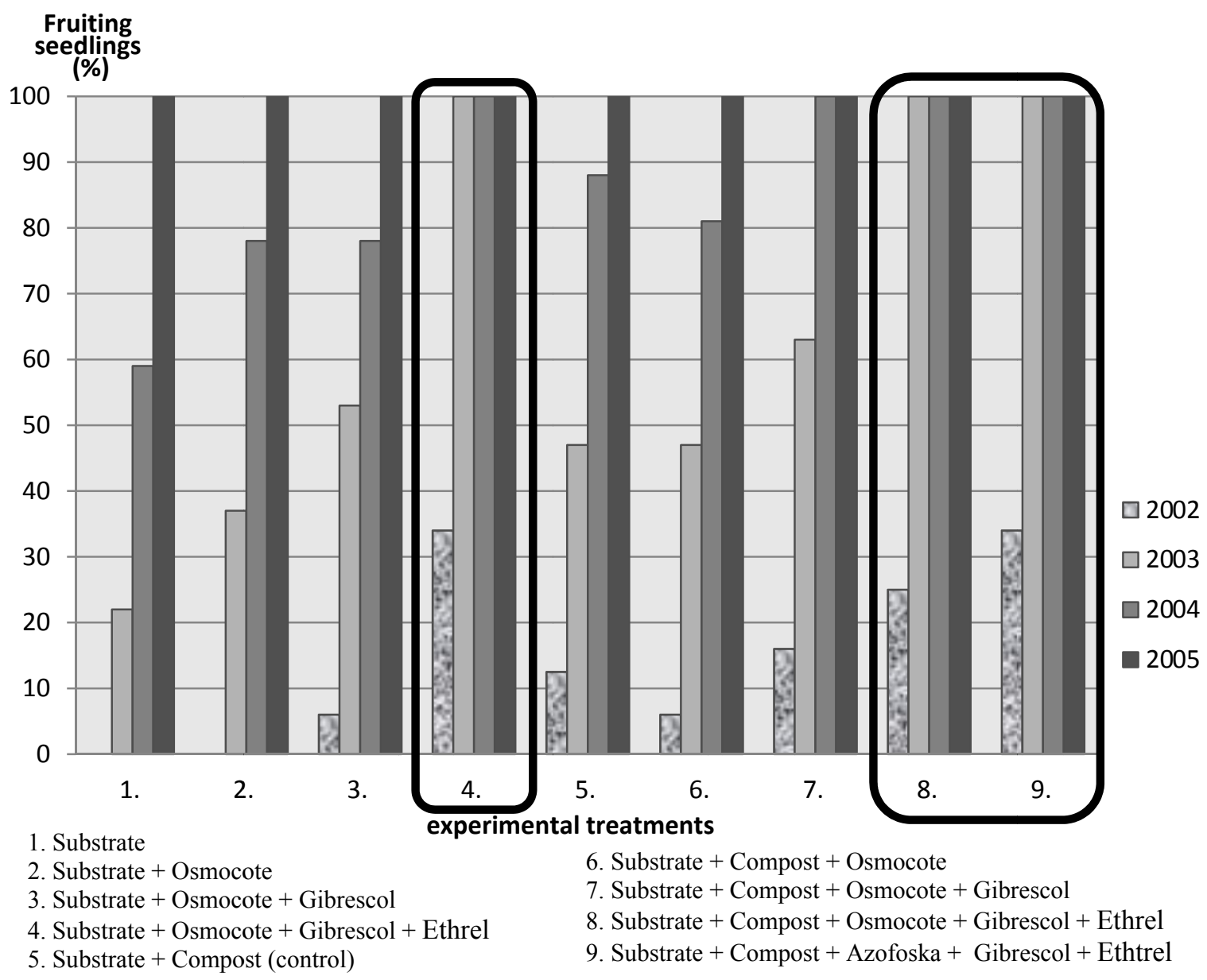

Figure 1. Percent of fruiting apple seedlings ('Ligol' $x$ 'Delbard Jubile') in the field on M.9 


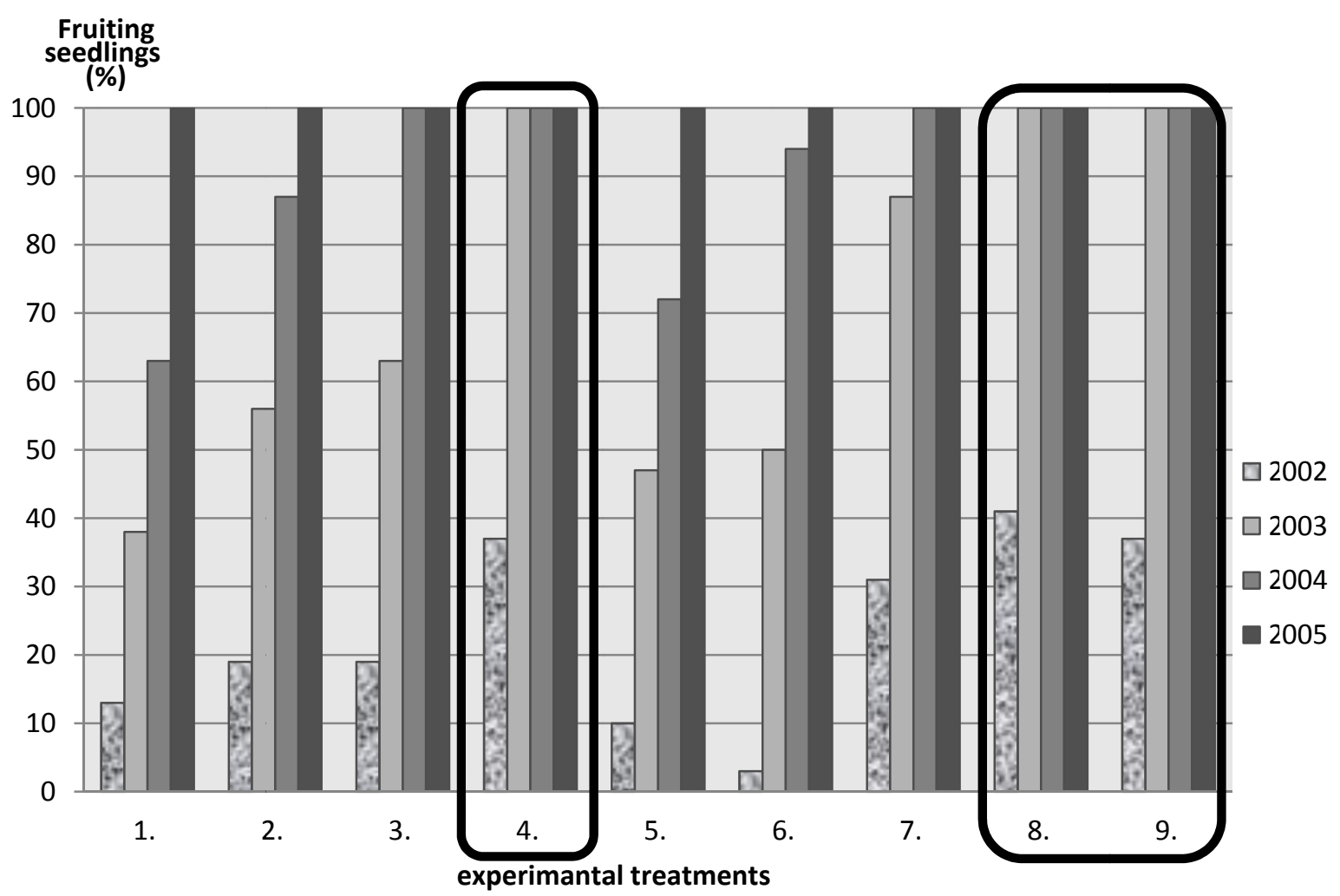

\section{Substrate}

2. Substrate + Osmocote

3. Substrate + Osmocote + Gibrescol

4. Substrate + Osmocote + Gibrescol + Ethrel

5. Substrate + Compost (control)
6. Substrate + Compost + Osmocote

7. Substrate + Compost + Osmocote + Gibrescol

8. Substrate + Compost + Osmocote + Gibrescol + Ethrel

9. Substrate + Compost + Azofoska + Gibrescol + Ethtrel

Figure 2. Percent of fruiting apple seedlings ('Linda' x 'Golden Delicious') in the field on M.9 


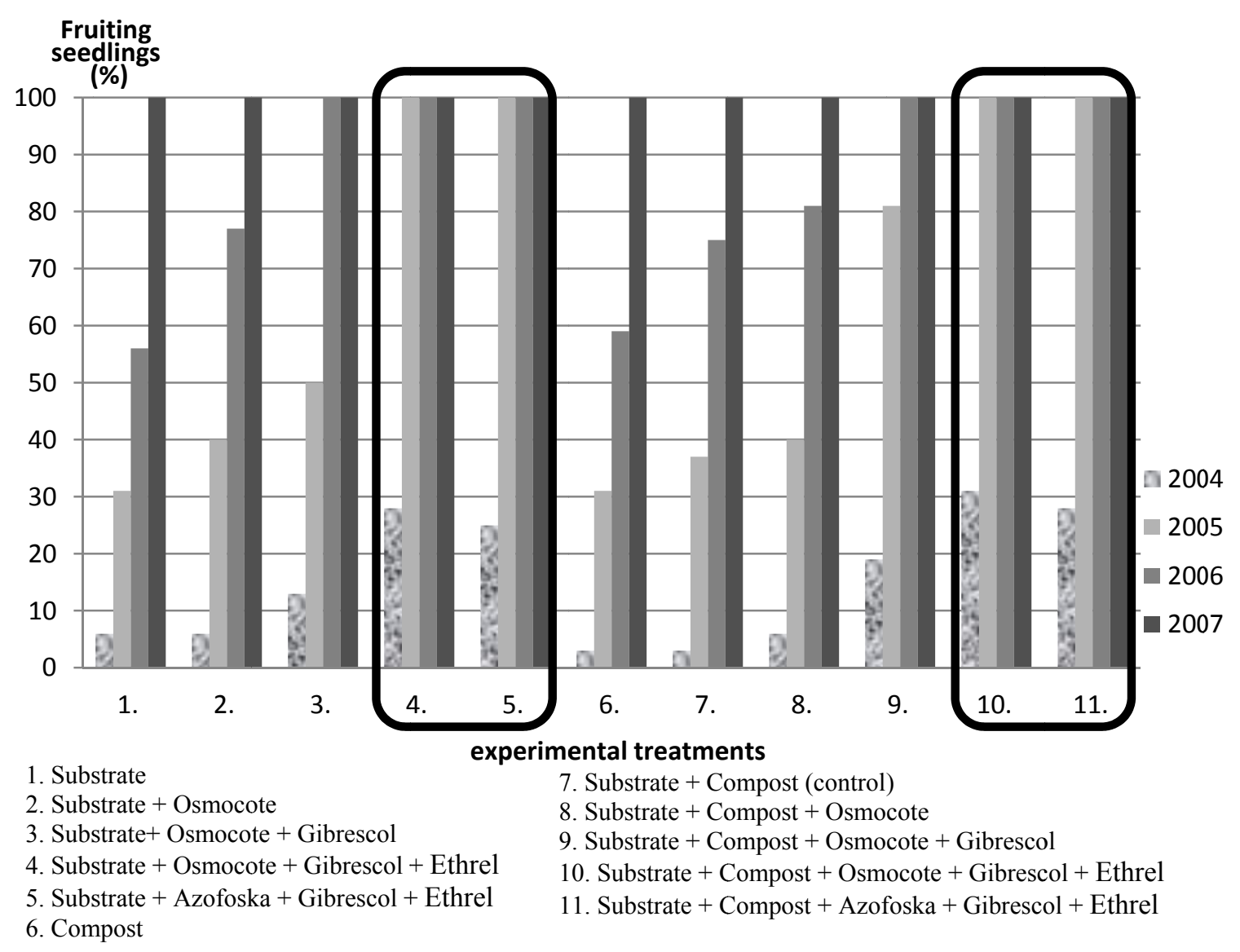

Figure 3. Percent of fruiting apple seedlings ('Free Redstar' x 'Melodie') on M.9 


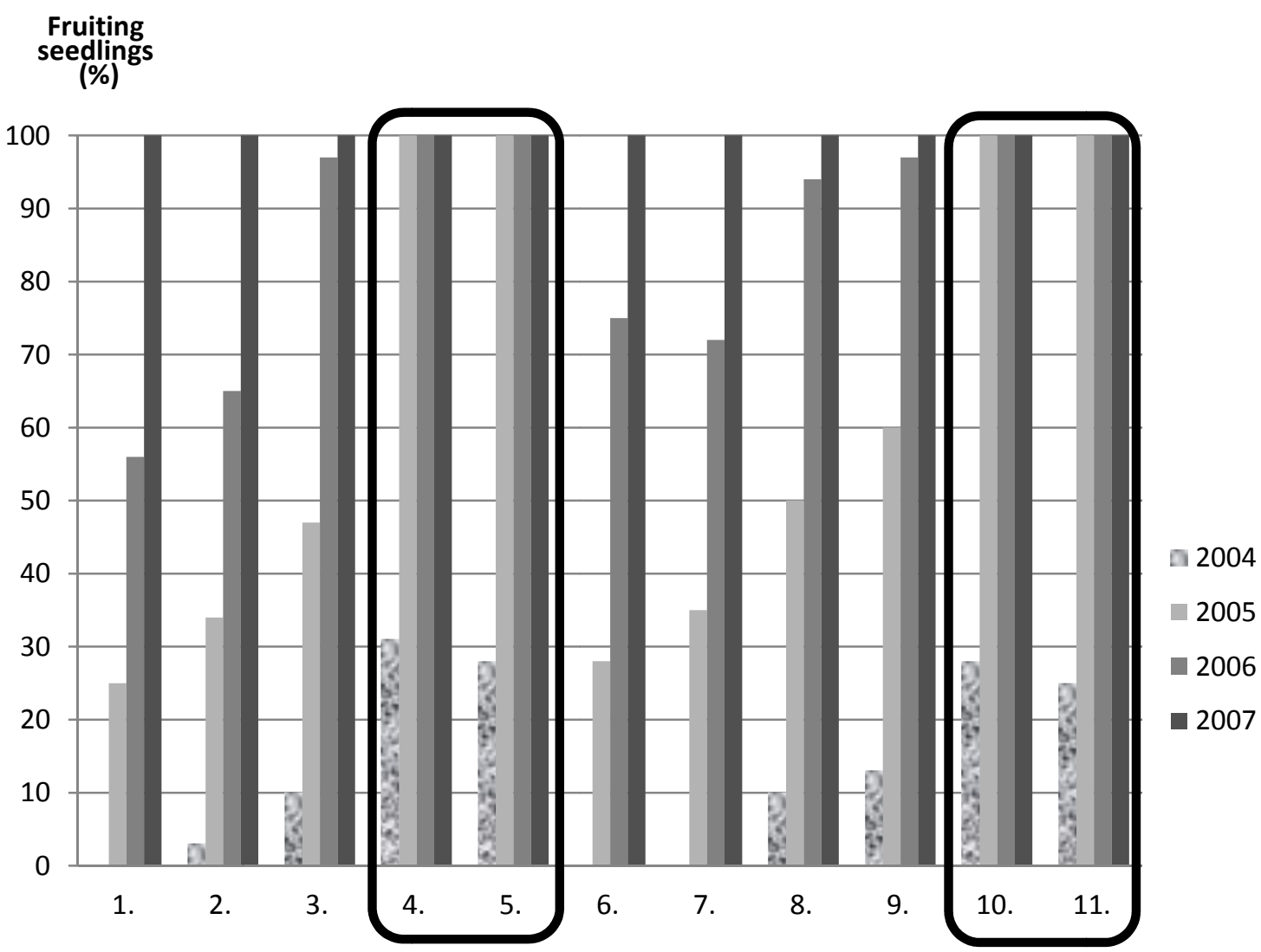

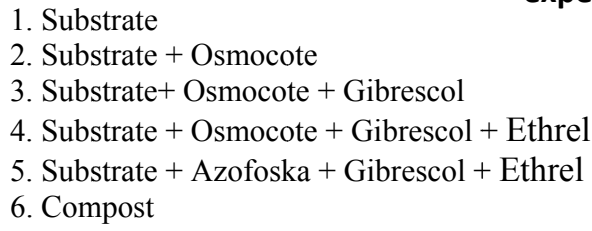

1. Substrate

2. Substrate + Osmocote

3. Substrate + Osmocote + Gibrescol

4. Substrate + Osmocote + Gibrescol + Ethrel

5. Substrate + Azofoska + Gibrescol + Ethrel

6. Compost

\section{experimental treatments}

\author{
7. Substrate + Compost (control) \\ 8. Substrate + Compost + Osmocote \\ 9. Substrate + Compost + Osmocote + Gibrescol \\ 10. Substrate + Compost + Osmocote + Gibrescol + Ethrel \\ 11. Substrate + Compost + Azofoska + Gibrescol + Ethrel
}

Figure 4. Percent of fruiting apple seedlings ('Free Redstar' x 'Coop 38') on M.9

\section{Conclussions}

Cultivation of young apple seedlings in containers in high plastic tunnels allows breeders to produce tall seedlings in a relatively short time. At the end of the first year, most of them reach the height of more than 100 $\mathrm{cm}$ and at the end of the second year of cultivation most of them are at least $200 \mathrm{~cm}$ tall. Both growing media peat substrate and compost soil are suitable for the cultivation of apple seedlings in containers in high plastic tunnels, however compost soil is less expensive than peat substrate. Mineral fertilizers - Osmocote and Azofoska are equally effective in promoting strong growth of apple seedlings cultivated in containers, but Azofoska is much more economical to use than Osmocote and can be a good substitute for Osmocote. Giberelic acid $\left(\mathrm{GA}_{3}\right)$ stimulates growth of apple seedlings cultivated in containers on their own roots in plastic tunnels as compared to the treatment without this bioregulator. Additional treatment of these seedlings with Ethrel does not affect their growth vigor. However, Ethrel applied on young apple seedlings cultivated in a high plastic tunnel shortens their juvenile period. In the first year after planting in the field $\left(4^{\text {th }}\right.$ year after seed germination) flowers are present on at least $25 \%$ of the seedlings, and in the second year $\left(5^{\text {th }}\right.$ year after seed germination) all seedlings $(100 \%)$ produce fruits suitable for evaluation.

\section{References}

Fischer, C. (1994). Shortening of the juvenile period in apple breeding.. In H. Schmidt, \& M. Kellerhals (Eds.), Developments in Plant Breeding: Progress in Temperate Fruit Breeding (pp. 161-164). Dordrecht, Boston, London: Kluwer Academic Publishers. http://dx.doi.org/10.1007/978-94-011-0467-8_32 
Flachowsky, H. (2009). A review on transgenic approaches to accelerate breeding of woody plasnts. Plant Breeding, 128, 217-226. http://dx.doi.org/10.1111/j.1439-0523.2008.01591.x

Guo, G. N., Guo, Z. N., \& Zan, S. Z. (1992). Effect of spraying growth retardants and ringing on the duration of the juvenile stage of apple seedlings. Journal of Fruit Science, 9(2), 99-102.

Hamad, W. J., \& Mohammad, A. A. (1990). Effect of Ethrel on vegetative growth, flowering and fruit characteristics of Ahmer Sayfi apple cultivar. Ann. Of Agri. Science (Cairo)., 35(1), 607-622.

Katzfuss, M., \& Schmidt, S. (1986). Ertragstabilisierung und Ertragsteigerung bei Apfel durch Anwendung von Wachstumsregulatoren. Archiv fur Gartenbau., 34, 285-295.

Kender, W. J. (1971). The induction of early fruiting in juvenile apple trees by 2-chloroethylphosphonic acid. HortSci., 6, 283 (Abstr.).

Luckwill, L. C. (1973). Growth regulators - their potential and limitations. Scientia Horticulturae, 24, 153-157.

Visser, T. (1964). Juvenile phase and growth of apple and pear seedlings. Euphytica, 13, 119-129.

\section{Copyrights}

Copyright for this article is retained by the author(s), with first publication rights granted to the journal.

This is an open-access article distributed under the terms and conditions of the Creative Commons Attribution license (http://creativecommons.org/licenses/by/3.0/). 